\title{
S. Bernadetta Żychlińska \\ OJCOSTWO BOGA WZGLĘDEM JEZUSA CHRYSTUSA I LUDZI W LISTACH ŚW. PAWŁA
}

\section{OJCOSTWO BOGA WZGLĘDEM JEZUSA CHRYSTUSA}

Tytuł Syn Boży oznacza jedyną i wieczną relację Jezusa Chrystusa do Boga, Jego Ojca: On jest jedynym Synem Ojca i samym Bogiem. Od początku Boże synostwo Jezusa stanowiło centrum wiary i kerygmatu apostolskiego; wiara w to synostwo jest konieczna, by być chrześcijaninem. Również w teologii Pawłowej Bóg jest przede wszystkim „Ojcem Jezusa Chrystusa" (ludzie stali się dziećmi Bożymi dopiero na podstawie dzieła zbawczego dokonanego przez Syna Bożego).

Myśl o Bogu jako Ojcu Jezusa ma swe główne źródło w chrystofanii pod Damaszkiem. O swoim nawróceniu na drodze do Damaszku św. Paweł powiedział:

„Gdy jednak spodobało się temu, który wybrał mnie jeszcze w łonie matki mojej i powołał łaską swoją, aby objawić Syna swego we mnie, bym Ewangelię o Nim głosił poganom..." (Ga 1,15-16).

Objawienie pod Damaszkiem, jak wiemy z Dziejów Apostolskich, było momentem przełomowym, rozstrzygającym o losie dotychczasowego prześladowcy chrześcijan, a także o losie chrześcijaństwa. „Zaraz też zaczął głosić w synagogach, że Jezus jest Synem Bożym” (Dz 9,20), każdorazowo podkreślając specyficzny związek i przynależność Jezusa do Ojca jako Boga, przy czym we wszystkich wypowiedziach syn jest równocześnie przedstawiany w swojej roli zbawczej. Prawdę o Bogu jako Ojcu ma św. Paweł przed oczami nawet wtedy, gdy nie mówi o tym wprost.

Dla św. Pawła Jezus Chrystus jest więc ucieleśnionym odwiecznym synem Boga (Rz 1,3n). Skoro Jezus jest ze swej istoty Synem Bożym, musiał zawsze istnieć przy Ojcu. Preegzystencję Jezusa i Jego synostwo Boże w szczególny sposób podkreślają Pawłowe hymny chrystologiczne. W dwóch zwłaszcza hymnach, pochodzących z tradycji, wypowiada św. Pawel, kim jest Chrystus w swej preegzystencji:

Flp 2,5-11 - opisuje sposób preegzystencji u Boga przed Wcieleniem i całą drogę zbawczą, w której centrum są dwa akty zbawcze: uniżenie aż po śmierć i wywyższenie;

Kol 1,15-20 - kładzie nacisk na kwalifikacje równości z Ojcem; Chrystus jako umiłowany Syn jest obrazem Boga niewidzialnego, jest 
dokładną kopią Boga, a jednocześnie autonomiczną osobą i przyczyną sprawczą stojącą przy Bogu w akcie stworzenia.

Chrystus jako zmartwychwstały Syn Boga jest punktem wyjścia myśli teologicznych Listu do Galatów i Listu do Rzymian (Ga 1,1; Rz 1,1-2). Z Ga 4,4 dowiadujemy się, że gdy nadeszła pełnia czasu, zesłał Bóg Syna. Osobowo pojęty Syn Boży w preegzystencji - staje się człowiekiem. Jezus, jako Syn Boży został zrodzony z niewiasty - wkroczył w dzieje ludzkości w punkcie kulminacyjnym Bożego objawienia. Historyczny Jezus jako człowiek jest inny od wszystkich ludzi (Rz 8,5-7). O tym decyduje Jego odwieczne pochodzenie od Boga.

\section{List do Kolosan - hymn o umiłowanym Synu Ojca}

W tym bogatym treściowo Liście fragment 1,15-20 stanowi hymn na cześć Chrystusa pośrednika w stworzeniu i odkupieniu. Hymn ten został wkomponowany w perykopę ukazującą misterium Chrystusa (Kol 1,12-2,15). Apostoł w uroczystej formie wzywa adresatów Listu do dziękczynienia Ojcu za to, że ich uzdolnił do uczestnictwa w dziale świętych w światłości, że ich uwolnił spod władzy ciemności i przeniósł do królestwa umiłowanego swego Syna, w którym mamy odkupienie (Kol 1,12-14). Wiersze następne (15-20), a więc słowa hymnu, który się składa z dwóch strof, pokazują kim jest ten umiłowany Syn - Odkupiciel:

„On jest obrazem Boga niewidzialnego. Pierworodnym wszelkiego stworzenia, bo w Nim zostało wszystko stworzone..." (1,15-16).

Idea „obrazu Boga” wywodzi się z myśli biblijnej i określa nie tylko podobieństwo jak w Rdz 1,27, ale i pochodzenie Chrystusa od Boga Ojca, zgodnie z najbliższym poprzedzającym kontekstem (w. 13-14), gdzie jest mowa o umiłowanym Synu, w którym mamy odkupienie i odpuszczenie grzechów. Preegzystujący Chrystus, przyczyna sprawcza, ostateczny cel i zasada wszelkiego stworzenia, jawi się jako odblask wiecznej światłości, zwierciadło bez skazy działania Boga, „obraz Jego dobroci” (Mdr 7,26) i jednocześnie ten, który pokazuje, objawia światu Boga. Ten drugi aspekt „obrazu”, tj. misja Chrystusa objawienia światu Boga, potwierdza dodany przymiotnik „niewidzialnego". Chodzi tu nie tylko o podkreślenie transcendencji Boga, ale i przypomnienie, że niewidzialny Ojciec daje się nam poznać jedynie przez Syna.

W omawianym hymnie św. Paweł określił stosunek Chrystusa nie tylko do Boga, ale i do całego stworzenia. Chrystus jest w nim przedsta- 
wiony jako pośrednik stworzenia i odkupienia. Wskazuje na to związek przyczynowy między stworzeniem i odkupieniem.

„Pierworodny wobec każdego stworzenia” - w Pawłowej chrystologii słowo pierworodny nie oznacza stworzenia Jezusa w czasie przed innymi stworzeniami, gdyz jest On preegzystującym Synem. Mówi o tym w. 16. Jeżeli Chrystus jest pośrednikiem stworzenia, nie może być stworzony jako pierwsze ze wszystkich stworzeń. Starotestamentalne pojęcie pierworodnego zawiera dwa aspekty, które widoczne są w tym tekście. Pierwszy chronologiczny: Chrystus zrodzony jest przed wszelkim stworzeniem skierowany jest ku transcendencji. Drugi - prawny: Chrystus ma pierwszeństwo w godności wobec każdego stworzenia i sprawuje nad nim władzę Pierworodnego - zwrócony jest ku stworzeniu. Zatem Chrystus jako Pierworodny posiada pierwszeństwo w sensie czasowym i w sensie godności w stosunku do „wszelkiego stworzenia”. Posiada władzę: „trony, władztwa, zwierzchności, potęgi”. Wszystko zostało stworzone „przez Niego i dla Niego". Jest przyczyna wzorczą, sprawczą, celową i zachowawczą (zasada istnienia, harmonii, jedności) wszechrzeczy.

Wiersze 16-18a zawierają uzasadnienie prymatu Chrystusa w porządku kosmicznym, jako obrazu Boga niewidzialnego oraz jako pierworodnego wobec każdego stworzenia (w. 15). Uzasadnieniem tym jest udział Chrystusa w dziele stworzenia: wszystko zostało stworzone „w Nim” (w. 16a), „przez Niego i dla Niego" (w. 16c). Użyte tutaj przyimki (w, przez i dla) określają trzy aspekty tego udziału Chrystusa w akcie stwórczym:

„w Nim” - zwraca uwagę na to, że Chrystus jest zasadą istnienia wszechrzeczy, która im nadaje jedność, harmonię, sens i wartość;

„przez Niego” - wyraża przyczynę narzędziową (sprawczą);

„dla Niego" - ukazuje Chrystusa jako cel całego stworzenia, jako Tego, któremu wszystko ma się podporządkować.

Wiersze 19-20 zawierają uzasadnienie prymatu Chrystusa w porządku soteriologicznym (zbawczym), wyrażonego zdaniem: „, On jest Początkiem, On pierwszy spośród umarlych narodził się do życia, aby On sam we wszystkim miat pierwszeństwo (w. 18b-d). Tym uzasadnieniem jest postanowienie Boga, aby dokonać dzieła odkupienia przez Chrystusa, w którym zgodnie z tymże dekretem - ,zamieszkała wszelka Pełnia”. Ta „Pełnia” w Chrystusie jest warunkiem Jego misji zbawczej i oznacza absolutną pełnię bytu.

Tak jak udział Chrystusa w dziele stworzenia dał Mu pierwszeństwo absolutne i władzę wśród wszystkich stworzeń, tak samo Jego udział 
w kosmicznym odkupieniu i pierwszeństwo w zmartwychwstaniu czyni zeń pierworodnego odkupionej ludzkości i zasadę nowego życia.

Misterium Chrystusa zatem to Jego absolutny prymat wynikający z Jego pośrednictwa $\mathrm{w}$ dziele stworzenia i odkupienia i to w skali kosmicznej (Chrystusowi zawdzięcza swoje istnienie nie tylko świat przyrodzony, ale i nadprzyrodzony).

\section{List do Filipian - hymn o kenozie i wywyższeniu Syna Bożego}

Fragment 2,6-11 Listu do Filipian to hymn o Chrystusie. Mówi o kenozie (uniżeniu), która dokonała się we wcieleniu, trwała przez całe Jego ziemskie życie i zakończyła się śmiercią na krzyżu. Hymn dzieli się na trzy strofy: preegzystencja (w. 6), wcielenie (w. 7-8) i wywyższenie Chrystusa (w. 9-11).

Chrystus zawsze istnieje jako Bóg - wyraża to imiesłów czasu teraźniejszego „istniejąc”, ale w określonym czasie przyjmuje ludzką naturę (tajemnica wcielenia) i nie ujawnia się w całym swoim majestacie i chwale. $\mathrm{Z}$ tego powodu, że dobrowolnie się uniżył, został w nagrodę wywyższony przez Ojca w naturze ludzkiej. Chodzi tu o wywyższenie wyjątkowe, najwyższe, absolutne. Wyniesienie Chrystusa polega na zmartwychwstaniu i wniebowstąpieniu, tj. zasiadaniu w niebie po prawicy Ojca $(\mathrm{Rz} 1,3 \mathrm{n} ; 8,34$; Ef 4,9n). Bóg darował Chrystusowi imię w najpełniejszym znaczeniu: $K y$ rios (Pan) równoznaczne jest $\mathrm{z}$ określeniem Bóg. To imię daje prawo do kultu adoracji. Powszechny kult należny Bogu (,w niebie, na ziemi i pod ziemią") przysługuje więc Chrystusowi (por. Rz 1,4; 1 Kor 16,22). Dla św. Pawła tytuł Pan jest tożsamy z tytułem Syn Boży. Tytuł Pan przysługuje odwiecznemu Synowi Bożemu z racji Jego wywyższenia przez zmartwychwstanie (por. Hbr 1,3n). Św. Paweł akcentując ideę o odwiecznym synostwie Bożym Jezusa Chrystusa - aby ją podkreślić i ujawnić w całej pełni w związku z wywyższeniem Chrystusa - mówi o Bogu i Ojcu Pana naszego Jezusa Chrystusa. Przy czym ma na uwadze dzieło zbawcze Pana wyrażone przez zaimek „nasz”. Jezus Chrystus jest jedynym i wyłącznym Panem naszej chrześcijańskiej egzystencji.

Hymn o kenozie kończy doksologia: „ku chwale Boga Ojca”. Wynika z niej, że wyznanie wiary w Chrystusa Pana ma na celu chwałę Boga Ojca (por. Rz 15,7-9; 2 Kor 1,20; Ef 1,6; 1 Kor 12,4-6; 15,28). 


\section{List do Rzymian - Jezus Chrystus pełnym mocy Synem Bożym}

W tym najbogatszym teologicznie Liście św. Paweł pisze, że dobra nowina ma na uwadze Chrystusa - Syna Bożego - dwa sposoby Jego bytowania. Są one uzależnione od dwóch wydarzeń: od zwykłego ludzkiego narodzenia się z rodu Dawida oraz od zmartwychwstania. Pierwszy fakt rzutuje na istnienie w ludzkim ciele i podleganie wszystkim procesom doczesnej egzystencji. Drugi natomiast ukazuje działanie Ducha Bożego w Chrystusie, dzięki czemu działanie Chrystusa odznacza się potęgą. Oznacza to niebieską intronizację Chrystusa - akt, poprzez który Bóg daje Mu własną, Bożą moc.

Zmartwychwstanie jest zatem potwierdzeniem boskiego synostwa Chrystusa, które ukazuje się teraz w mocy Jego uwielbionego człowieczeństwa; Jezus został „ustanowiony według Ducha Świętości pełnym mocy Synem Bożym przez powstanie z martwych" (Rz 1,4).

Posiadanie mocy jest właśnie uzależnione od zmartwychwstania, które jest aktem mocy Bożej (Ef 1,19-20; 2 Kor 13,4; por. 1 Kor 15,43). $\mathrm{W}$ ten sposób Jezus objawia się w pełni jako Syn Boży - namaszczony, królujący, rozciągający swą władzę nad narodami. Opis chwały niebiańskiej zawarty w Rz 1,4 jest bliski opisowi w hymnie Flp 2,6-11.

\section{Tytuły godnościowe Chrystusa: Syn Boży i Pan}

Św. Paweł kreśli bezpośrednią zależność Syna od Ojca. Mówiąc o Synu włącza w to określenie myśl o preegzystencji i niezwykłej bliskości Syna do Ojca. Jednocześnie wypowiedzi dotyczące preegzystencji Syna pozwalają podkreślić stosunek Chrystusa jako pośrednika w stworzeniu do stworzenia (,pierworodny wobec...”).

Dzieło zbawcze rozpoczęło się objawieniem się odwiecznej tajemnicy, jaką jest Syn Boży. Kreśląc koniec tego dzieła św. Paweł mówi o Chrystusie, że „sam Syn podporządkowuje się Bogu” i przekaże Ojcu wszystko , aby Bóg był „wszystkim we wszystkich” (1 Kor 15,28). Syn podporządkowuje się Bogu jako człowiek, bo jako Bóg jest równy Ojcu. Według natury ludzkiej Jezus jest potomkiem Dawida, ale na planie Ducha Bóg ustanowił Go swoim Synem i potwierdził to jasno i z mocą poprzez zmartwychwstanie (Rz 1,3-4). Zmartwychwstanie Jezusa - w sensie powołania ziemskiego Jezusa do nowego życia - jest więc dokumentacją, że Jezus jest prawdziwym Synem Bożym. Dlatego też wywyższenie Jezusa dokonało się „ku chwale Boga Ojca” (Flp 2,11). 
Po uniżeniu Syna aż do posłusznego aktu śmierci, zostaje On wywyższony i otrzymuje imię, które jest ponad wszelkie imię: Kyrios (Pan). Zarówno określenie Syn Boży, jak i Pan stały się u św. Pawła tytułami godnościowymi (jest to tytulatura przejęta z tradycji). Tytuł Syn Boży wskazuje na silne powiązania Syna z Bogiem. Przez te dwa tytuły chrystologiczne została zasygnalizowana droga zbawcza Jezusa Chrystusa. Rozpoczyna się ona posłaniem odwiecznego Syna Bożego na świat, a kończy wywyższeniem jako Pana.

U podstaw tej drogi stoi Bóg jako jej inicjator. W związku z tytułem Syn Boży zmartwychwstanie i wywyższenie jest dziełem Boga, ale tez śmierć krzyżowa jest dziełem Boga. Św. Paweł podejmując starsze formuły mówi, że Bóg wydał Syna, podkreśla jednak równocześnie dobrowolne wydanie się Jezusa. Syn umierając na krzyżu w ludzkim ciele dokonał z woli Boga Ojca odkupienia (Kol 1,22). Krzyż wieńczy posłuszeństwo Syna. A Syn poprzez zmartwychwstanie doznaje nowego potwierdzenia swojego synostwa Bożego.

Tytuł Syn Boży, znany z tradycji, która sięga samego Jezusa, doznał nowych implikacji u św. Pawła, idących zwłaszcza w kierunku idei naszego synostwa Bożego.

\section{OJCOSTWO BOGA WZGLĘDEM LUDZI}

Ideę ojcostwa Bożego - i konsekwentnie ideę dziecięctwa Bożego spotykamy już w Starym Testamencie. Naród wybrany jest nazywany „pierworodnym synem Boga” (Wj 4,22). Bóg jest Ojcem Izraela (Pwt 32,6; Iz 63,16; 64,7). W Syr 23,14 odnajdujemy wezwanie: Panie, Ojcze i władco mojego życia... Panie, Ojcze i Boże mojego życia". W Mdr 14,3 czytamy: Twoja zaś opatrzność, Ojcze, kieruje...".

Św. Paweł znał te starotestamentalną naukę o dziecięctwie Bożym, ale w swoich Listach przedstawia inną, będącą niewątpliwie kontynuacją, ale i udoskonaleniem tamtej: naukę o synostwie Bożym, wynikającym z faktu posiadania Ducha Świętego.

Podstawowym tekstem o Bożym ojcostwie jest 2 Kor 6,15-7,1. Św. Paweł podkreśla w nim, że przybrane synostwo Boże to nie tylko wielki i wyjątkowy przywilej, lecz także obowiązek życia w świętości, dążenie do upodobnienia się do Boga. Nawiązuje do Starego Testamentu. Swobodnie zestawia kilka tekstów (Iz 52,11; Ez 20,34; 2 Sm 7,8.14; Iz 43,6; Jr 31,9), na potwierdzenie tego, że chrześcijanin jest własnością Boga, należy do sfery Bożej i nie może prowadzić grzesznego życia. Na stosunek ojcostwa 
i miłości wskazuje wyrażenie: Będę wam Ojcem, a wy będziecie moimi synami i córkami (w. 18a). Nie chodzi oczywiście o bojaźń niewolniczą, lecz synowską, którą utożsamiać trzeba z szacunkiem, z pełnym oddaniem człowieka Bogu - Ojcu Niebieskiemu. Św. Paweł uczy, że do Ojca iść można tylko z pochyloną głową licząc na Jego miłosierdzie $(\mathrm{Rz} 9,16)$.

Dwa wielkie teologiczne traktaty dogmatyczne o przybranym synostwie Bożym to List do Rzymian 8 i List do Galatów 4:

- w Ga 4 chodzi o uwolnienie się spod prawa; zbawienie jest owocem wiary w Jezusa Chrystusa, chrześcijanie jako synowie Boży stają się dziedzicami obietnic Bożych;

- w Rz 8 św. Paweł mówi o wolności dzieci Bożych, uzmysławia adresatom prawdę, że synostwo Boże polega na dojrzałości i odpowiedzialności chrześcijańskiej; zachęca wiernych do „umartwienia czynów ciała” $(8,13)$, oraz do „współcierpienia” z Chrystusem $(8,17)$ - z tego cierpienia rodzi się pragnienie wolności i chwały synów Bożych.

\section{Prawo Starego Przymierza przygotowaniem do wolności dzieci Bożych}

Stary Testament i zawarte w nim Prawo jest historią zbawczych obietnic (Rz 4,13-15; Ga 3,17n). Św. Paweł dowodzi, że Stary Testament przygotował naród na przyjście Chrystusa (1 Kor 10,11).

Prawo, choć jest niższe, nie stoi w sprzeczności z obietnicami Bożymi. Stałoby gdyby - jak twierdzą judaizujący - było źródłem życia Bożego. Tymczasem rola Prawa jest inna. Św. Paweł wyjaśnia (Ga ?,21), że jak to dokumentuje Pismo Św. - cała ludzkość znalazła się w niewoli grzechu (por. Rz 3,10-18). Z niewoli tej nie uwolniło nas Prawo, lecz wiara w Jezusa Chrystusa.

Język św. Pawła jest metaforyczny: grzech trzyma w więzieniu ludzkość, Prawo jest strażnikiem, który pilnuje murów więziennych. Prawo Starego Przymierza było więc tylko przygotowaniem. Lud Boży był zamknięty w przykazaniach jak w fortecy. Był chroniony, ale nie miał wewnętrznej wolności. Inna metafora - obraz wychowawcy $(\mathrm{Ga} 4,1)$ - ukazując rolę Prawa, które doprowadza podopiecznych do Chrystusa, tak jak niewolnik prowadził dzieci swego pana do szkoły greckiej. Teraz Jezus jest prawdziwym Nauczycielem, a my już nie potrzebujemy, by nas prowadzono jak dzieci. Skoro nadeszły czasy wiary, skończyła się rola Prawa i dlatego przestało ono obowiązywać. 
Ludzie byli dotychczas „w niewoli żywiołów tego świata”: wola Boga, ich Ojca, została im podana przez nakazy, reguły zewnętrzne instytucji hebrajskich, czy pogańskich, które utrzymywały ich w stanie poddaństwa. Przybycie Jezusa stanowi jakby dojście do wieku dorosłego i do wolności: Syn Boży staje się człowiekiem urodzonym z kobiety podobnie jak my, toteż my możemy tak jak On stać się synami Bożymi (Ga 4,4-10). On poddaje się Prawu Mojżeszowemu, aby nas włączyć w swoje bogactwo (Ga 4,1-4).

Ludzie związani Prawem przeszli więc ze stanu dziecięcej niedojrzałości w stan dojrzałego człowieka, ze stanu niewoli do wolności. Jesteśmy synami Bożymi - dojrzałymi, ufnymi, wolnymi. To skutki chrztu otrzymanego w wierze; wiara sprawiła, że posiadacze jej stali się synami Bożymi (Ga 3,26-27), a chrzest przyoblekł neofitę w Chrystusa, łącząc człowieka z Bogiem Ojcem, Chrystusem i Duchem Świętym. Odtąd nie liczą się dawne podziały, wszyscy tworzymy jedno ciało, mamy nowe istnienie z Jezusem Chrystusem.

Zjednoczenie z Chrystusem napełnia chrześcijanina potęgą Ducha Świętego. Potęga ta uwalnia od tyrani grzechu i śmierci. Tak więc dzięki Duchowi Świętemu ustaje zewnętrzna, legalistyczna forma Prawa. Staje się ono odtąd zinterioryzowane. To, co było przymusem wynikającym z nakazu Prawa, stało się wewnętrzną potrzebą wynikającą z miłości Boga.

I działanie Ducha Świętego i uwolnienie człowieka spod panowania Prawa dokonało się dzięki decyzji Boga Ojca, który „wysłał swego Syna” (Rz 8,3), by jako człowiek zbawiający całą ludzkość umożliwił wypełnienie poleceń Prawa, ponieważ On dał swoim wierzącym Ducha Świętego.

\section{Przybrane synostwo - stworzenie „nowego człowieka”}

Chrześcijanin, zdaniem św. Pawła, to człowiek objęty specjalnym działaniem Boga Ojca, Chrystusa i Ducha Świętego, człowiek wiary „nowy człowiek”. Chrześcijanin zawdzięcza zatem swą nową egzystencję działaniom całej Trójcy Świętej.

Skrótowe, ale kompletne ujęcie dzieła Boga Ojca - dzieła mającego na celu wyniesienie człowieka do godności chrześcijańskiej - daje św. Paweł w Rz 8,28-30.

Jeśli Bóg kogoś wybrał i przeznaczył, to wszystko - niezależnie od układu zdarzeń doczesnych - na pewno posłuży ostatecznie dobru wybranego. Św. Paweł przedstawia tutaj Boże działanie jako zespół aktów podporządkowanych sobie zarówno chronologicznie jak i logicznie. Oto one: 
zamiar Boży, „przewidzenie”, przeznaczenie, powołanie, usprawiedliwienie, obdarzenie chwałą. Za pośrednictwem tych właśnie aktów dokonuje się stworzenie nowego człowieka - chrześcijanina.

Ze współdziałania Ducha Świętego z chrześcijanami wynika, że wszystko, co ich spotyka, przymnaża im dobra. Jest to naturalna konsekwencja, ponieważ jeszcze przed stworzeniem świata Bóg przeznaczył ludzi - poprzez swoją wielka miłość - do odtwarzania w sobie wzoru, jakim jest Chrystus. Człowiek zatem ma być przemieniony na podobieństwo Chrystusa, ma być Jego obrazem (por. 1 Kor 15,49; 2 Kor 3,18; Kol 1,18; 3,10; Ef 4,20-24). Ponieważ Chrystus jest obrazem Ojca (Kol 1,15), więc chrześcijanin noszący w sobie obraz Syna (Rz 8,16-17) (stąd On jest pierwszy wśród innych ludzi) staje się upodobniony do Ojca i dlatego może się również nazywać synem Boga. Upodabnianie to dokonuje się powoli i stopniowo, aż do pełni, która zaistnieje w paruzji $(1$ Kor 15,49). Na tym polega przeznaczenie ludzi przez Boga, którzy dla odtworzenia w sobie podobieństwa Chrystusa i Ojca zostali wezwani, usprawiedliwieni i obdarzeni chwałą.

O wyborze i przeznaczeniu mowa jest też w Ef 1,4-5. Przeznaczenie to dokonało się jeden raz - do synostwa Bożego w sensie teologicznym, a nie jurydycznym. Jest to synostwo przybrane. Oznacza więcej niż adopcja prawna, gdyż daje udział w boskiej naturze (Bóg w nas zamieszkuje), ale mniej niż naturalne synostwo (naturalnym Synem Ojca jest tylko Jezus Chrystus). Przez to synostwo z przybrania jesteśmy dziedzicami królestwa niebieskiego, jesteśmy dopuszczeni do tajemnic Bożych. Obecność Boża powoduje przemianę w chrześcijaninie. Dusza ludzka rzeczywiście staje się świątynią Boga żywego (1 Kor 3,16).

Przybrane synostwo Boże otrzymują chrześcijanie dzięki Jezusowi, jedynemu pośrednikowi (por. 1 Tm 2,5), który przez odkupienie przywraca utraconą łaskę. Synostwo przybrane polega na życiu Bożym. „Zgodnie z postanowieniem swej woli" - zwrot ten oznacza całkowitą i odwieczną wolność Boga, który ze swego upodobania obsypuje chrześcijan wiekuistymi dobrami, wszystkimi łaskami, przede wszystkim łaską przybrania za synów i dodaje jeszcze dary charyzmatyczne: mądrość do wnikania w tajemnice Boże oraz roztropność do postępowania prawdziwie chrześcijańskiego. To ukazuje Jego wspaniałomyślność.

Jak wynika z Ef 1,4-6, chrześcijanie mieli swe miejsce w planach Bożych jeszcze przed stworzeniem świata. Już wtedy zostali wybrani i przeznaczeni - wybrani „w Chrystusie”. Bóg powziął decyzję zbawienia 
ludzi przez Chrystusa, przewidując jednocześnie Jego wcielenie i nasze uczestnictwo w zasługach Chrystusa.

Wykonawcą planu Bożego wobec człowieka jest zatem Jezus Chrystus, sam zaś plan realizuje się najpełniej poprzez łączność człowieka z Chrystusem. Więź z Chrystusem, zdaniem św. Pawła, stanowi zasadę życia chrześcijańskiego - i to zarówno tego, które chrześcijanin prowadzi obecnie, jak i życia pełnego, doskonałego, eschatologicznego (1 Tes 4,17).

Odkupieni grzesznicy stają się uczestnikami chwały Chrystusa $($ Ef 1,6$)$ z tytułu adoptowanego synostwa (Rz 8,17; Ga 4,7). Ta przemiana dokonuje się mocą nadprzyrodzonej wiary (Ef 1,8), którą Bóg daje człowiekowi żądając nowego, godnego Boga życia. Praktycznym wyrazem wiary jest przyjęcie chrztu. Chrzest natomiast jest zanurzeniem w śmierć Chrystusa, a dzięki temu też w Jego zmartwychwstanie, jest więc ,aktem adopcji”.

\section{Duch Święty przyczyną sprawczą Bożego synostwa chrześcijan}

Sprawcą przemian, jakie zachodzą w człowieku objętym Bożym planem zbawienia, jest Duch Święty. O tym, jak mocno akcentuje św. Paweł rolę i przeobrażające działanie Ducha Świętego, świadczy fakt, że terminem pneuma posługuje się w swych listach aż 146 razy.

Duch Święty jest dobrem, którego udziela nawróconym sam Bóg Ojciec. Ojciec wysyła Syna i Ducha Świętego - posłannictwo Syna i Ducha Świętego jest więc jedno: Syn został zesłany, aby ludzie otrzymali synostwo Boże, Duch Święty jest natomiast gwarantem tego synostwa, uświadamiając ludzi o ich godności i pobudzając ich do dziecięcej modlitwy do Ojca. Działanie Ducha jest tak zespolone z człowiekiem, że św. Paweł mógł napisać: ,żyjemy dzięki Duchowi” i dać zachętę: „,postępujmy równié̇ zgodnie ze wskazaniami Ducha" (Ga 5,25).

Rolę Ducha Świętego ukazuje św. Paweł w Liście do Rzymian (8,14-16), w którym mówi o wolności dzieci Bożych udzielonej im przez Ducha i przyszłej chwale zmartwychwstania. Rola ta polega na ciągłym przypominaniu o darze synostwa Bożego: ,,Ten właśnie Duch świadczy wobec naszego ducha, że jesteśmy dziećmi Boga... dzięki czemu możemy wołać: Abba! Ojcze!"

Wołanie to świadczy o dziecięcej miłości wierzących wobec Ojca, a więc o głębokim z Nim zjednoczeniu. Tak zjednoczony z Bogiem człowiek - syn Boży - stanowi jedność z innymi ludźmi - synami Bożymi, 
którzy również są zjednoczeni z samym Bogiem, tworząc społeczność dzieci Bożych: nowy lud Boży - Kościół.

Duch Święty został dany chrześcijanom w określonym celu: aby dopełnić realizacji planu Bożego wobec człowieka - planu sprowadzającego się do tego, by ludzie , upodobnili się do obrazu Syna Jego: aby On byt pierworodnym wśród wielu braci" (Rz 8,29). Został dany nie jednorazowo i sporadycznie, lecz jako trwała zasada i gwarancja przeobrażeń dokonujących się w osobie człowieka ochrzczonego.

Duch Święty zatem uświęca nas i czyni dziećmi Bożymi. Św. Paweł pisze o tym najdobitniej w tekście Rz 8,14n (por. Ga 4,6). Ogólne określenie synostwa Bożego zawarte w Rz 8,14n ma charakter skrótu. Nie wspomina ani o wierze, ani o chrzcie, ani o łączności z Ojcem i Synem Bożym. Zaakcentowane jest natomiast upewnienie człowieka o otrzymanym synostwie Bożym właśnie dzięki świadectwu, czyli udzielonemu przez Ducha przeświadczeniu o tym synostwie. Dzięki temu możemy wołać do Boga: „Abba, Ojcze!”, a więc odnosić się do Niego z dziecięcą serdecznością. Na tą serdeczność wskazuje aramejskie słowo $A b b a$ - słowo, które używało dziecko wobec swego ojca (tato).

Zjednoczenie z Chrystusem wprowadza ochrzczonego w sferę boskiego życia i sprawia, że ochrzczeni stają się w sensie duchowym potomkami Abrahama (Ga 3,29), spadkobiercami obietnic, które on niegdyś od Boga otrzymał, i otrzymują synostwo Boże (Ga 4,5-7). Dowodzi tego Duch Święty wołając w nas do Boga: „Ojcze!”. Jest On Duchem Syna Bożego wysłanym przez Ojca i Syna. Człowiek jako dziecko Boże jest zatem „spadkobiercą" tych dóbr razem z Chrystusem. Jest więc tak dalece zjednoczony z Chrystusem i tak dalece Synem Bożym, że ma równe prawo do dziedzictwa razem z jednorodzonym Synem Bożym (Rz 8,17).

Chrześcijaństwo jest więc posiadaniem Ducha Świętego, wysłanego przez Ojca i Syna. Jest uwielbieniem i zbawieniem, a jednocześnie oczekiwaniem - w głębokiej nadziei - czegoś więcej: ,,pełnego synostwa - odkupienia naszego ciała" (Rz 8,23). Jesteśmy ludźmi radosnej nowiny. W tęsknym czekaniu wspomaga nas Duch Święty. On przekształca nas wewnętrznie, uczy modlitwy, On też ukazuje jej właściwy przedmiot, On współdziała z chrześcijanami - synami i córkami Boga $(2$ Kor 6,18) - w każdym szczególe życia. 


\section{Synostwo Boże chrześcijan darem i zobowiązaniem do świętości.}

Wspólnota śmierci i zmartwychwstania z Chrystusem sprawia, że chrześcijanin staje się nowym człowiekiem, usprawiedliwionym i wiodącym nowe życie, które odznacza się brakiem grzechu i sprawiedliwością (Rz 6). W ten sposób uwidacznia się tymczasowa rola Prawa, które z chwilą przyjścia Chrystusa na świat straciło rację swojego bytu ( $\mathrm{Rz} 7)$. Chrześcijanin przestał być niewolnikiem Prawa, stał się poddanym prawu Ducha Bożego i dzięki temu mieszka w nim Duch Święty. Odtąd człowiek jest dzieckiem Bożym, a także spadkobierca dóbr Bożych, które polegają na uczestnictwie w Bożej chwale. Dzięki temu cała dotychczasowa ziemska egzystencja ludzka nabiera głębokiego sensu i uzasadnienia (Rz 8). Wszystko dobro otrzymane od Boga jest skutkiem Jego wolnego wyboru, podyktowanego jedynie miłosierdziem (Rz 9-11). Chrześcijanin świadomy tych dobrodziejstw musi ustawicznie konkretyzować swoją wiarę, która zawsze trwa, jak również zawsze trwa chrzest, bo zawsze trwa rzeczywistość zainicjowana przez wiarę i chrzest: stan Bożego synostwa. Wiara konkretyzująca się w codziennym życiu, to: miłość. Posłuszeństwo, wyrozumiałość... - to wszystko, czego przykładem jest życie Jezusa (Rz 12-15). Chrześcijanin jest zobowiązany do podejmowania wciąż na nowo wysiłków do walki z grzechem i pogłębiania świętości. Motywem takiej postawy jest bojaźń Boża rozumiana jako szacunek i pełne oddanie Bogu Ojcu. Dobre uczynki spełniane przez chrześcijanina nie są już uczynkami Prawa, lecz owocem działalności obecnego w dziecku Bożym Ducha Świętego, który dopełnia realizacji planu Bożego, polegającego na upodobnieniu się do synów i córek do Boga.

Gorzów Wielkopolski

S. BERNADETTA ŻYCHLIŃSKA

\section{Ks. Jan Józef Janicki}

\section{UCZESTNICTWO WIERNYCH W PASCHALNYM MISTERIUM}

Sobór Watykański II podkreślił ważność uczestnictwa ludu chrześcijańskiego w liturgii na sposób ,pełny, czynny i społeczny” (KL 21), pouczając, iż liturgia ma być sprawowana nie tylko ważnie i godziwie, lecz także w taki sposób, by wierni uczestniczyli w niej świadomie, czynnie i owocnie (por. KL 11). 